\title{
CCR5 Expression and $\beta$-Chemokine Production During Placental Neonatal Monocyte Differentiation
}

\author{
DYLAN ZYLLA, YUAN LI, EMILY BERGENSTAL, JEFFREY D. MERRILL, \\ STEVEN D. DOUGLAS, KATHY MOONEY, CHANG-JIANG GUO, LI SONG, AND WEN-ZHE HO \\ Division of Immunologic and Infectious Diseases [D.Z., Y.L., E.B., S.D.D., C-J.G., L.S., W-Z.H.], Division \\ of Neonatology [J.D.M., K.M.], The Children's Hospital of Philadelphia, Department of Pediatrics, \\ University of Pennsylvania School of Medicine, Philadelphia, Pennsylvania, U.S.A.
}

\begin{abstract}
The stage of maturation of monocytes affects their susceptibility to HIV infection. The $\beta$-chemokines and their receptor CCR5 play a crucial role in inflammatory reactions and HIV infection. We therefore examined the correlation between the expression of CCR5 and $\beta$-chemokine production and the susceptibility to HIV infection during cord monocyte (CM) differentiation into macrophages. $\mathrm{CM}$ and $\mathrm{CM}$-derived macrophages (CMDM) were examined for $\beta$-chemokine and CCR5 expression. The susceptibility of the CM cultured in vitro at different time points to HIV infection was also determined. Although the levels of CCR5 mRNA expression in freshly isolated CM are comparable to those in CMDM, CM had significantly lower levels of CCR5 protein on the cell surface than CMDM did. Steady increase of CCR5 protein expression on the cell surface was observed during $\mathrm{CM}$ differentiation into macrophages. The CCR5 expression correlated with the increased susceptibility to HIV infection by CMDM. Although there was no significant
\end{abstract}

\section{ABSTRACT}

difference in endogenous $\beta$-chemokine production between $\mathrm{CM}$ and CMDM, HIV infection of CMDM significantly enhanced production of macrophage inflammatory protein- $1 \alpha$ and $-1 \beta$. CCR5 receptor plays a critical role in HIV infection of neonatal blood monocyte/macrophages. (Pediatr Res 53: 853-858, 2003)

\[ \text { Abbreviations } \]
CM, cord monocytes
CMDM, cord monocyte-derived macrophages
MIP-1 $\alpha$, macrophage inflammatory protein-1 $\alpha$
MIP-1 $\boldsymbol{\beta}$, macrophage inflammatory protein-1 $\beta$
RANTES, regulated upon activation, normal T-cell expressed
and secreted
IFN- $\gamma$, interferon gamma
DMEM, Dulbecco's modified eagle medium
RT, reverse transcriptase
LPS, lipopolysaccharide

Macrophages are a major target of infection by HIV type 1 (HIV), and serve as an important reservoir for transmitting the virus to other immune cells such as $\mathrm{CD}^{+}{ }^{+} \mathrm{T}$ lymphocytes (1, 2 ). The $\beta$-chemokine receptor CCR5 plays an important role in nonsyncytium-inducing HIV strain infection of monocytes/ macrophages (3-5). The high resistance to infection by $\mathrm{M}$ tropic HIV strains in individuals homozygous for the CCR5 $\Delta 32$ mutation confirms that CCR5 is a major co-receptor for HIV (6-9). The natural ligands of CCR5 receptor, macrophage MIP- $1 \alpha$, MIP- $1 \beta$, and RANTES, inhibit infection by interfering with HIV binding to the CCR5 receptor $(3,10-12)$. Thus,

Received May 14, 2002; accepted September 30, 2002.

Correspondence: Wen-Zhe Ho, Division of Immunologic and Infectious Diseases, The Children's Hospital of Philadelphia, 34th St. \& Civic Center Blvd., Philadelphia, PA, 19104, U.S.A.: e-mail: Ho@email.chop.edu

Supported by grants from the National Institutes of Health (MH 49981, DA12815, and DA16022), and the W.W. Smith Charitable Foundation. D.Z. was a recipient of the Elizabeth Glaser Pediatric AIDS Foundation Student Intern Award.

DOI: 10.1203/01.PDR.0000059749.82140.4A the levels of CCR5 expression and $\beta$-chemokine production directly influence HIV infection of monocytes and macrophages. Because the levels of CCR5 present on the cell surface determine the susceptibility of monocyte/macrophages to HIV infection, gaining an understanding of the mechanism that regulates the expression of this receptor on monocytes and macrophages is critical.

The immaturity of the neonatal immune system may play an important role in the immunopathogenesis of pediatric viral infections, including HIV. When compared with adult cells, neonatal monocyte/macrophages are selectively abnormal or immature in various aspects of phagocytosis (13), chemotaxis $(14,15)$, metabolism (16), and production of $\operatorname{IFN}-\gamma(17,18)$. We have recently shown that cord blood mononuclear cells have selective defect in RANTES production compared with adult cells (19). The neonate and fetus are particularly susceptible to severe and fatal disseminated illness, including certain viral, parasitic, and bacterial infections. Infants infected with HIV perinatally have more rapid and fatal course than old 
children and adults. We (1) and others $(20,21)$ have documented that neonatal monocyte-derived macrophages are more susceptible to HIV infection in vitro than adult peripheral blood monocyte-derived macrophages. As monocytes differentiate into macrophages, they become highly susceptible to HIV infection (22-25). CCR5 expression during adult peripheral blood monocyte differentiation in vitro is directly related to macrophage susceptibility to HIV infection $(24,26)$. Although a great deal is known about CCR5 regulation in adult monocyte and monocyte-derived macrophages, little information is available about CCR 5 expression, $\beta$-chemokine production, and their relationship to HIV infection during neonatal monocyte maturation in in vitro cultures. Because the regulation of $\beta$-chemokines and their receptor CCR5 during neonatal monocyte differentiation into macrophages has potential implication in pediatric inflammatory diseases, including HIV infection of neonatal immune cells, we investigated the relationship between CCR5 expression and $\beta$-chemokine production with susceptibility to HIV infection during neonatal monocyte differentiation into macrophages.

\section{MATERIALS AND METHODS}

Cell isolation. Placental cord blood was obtained from healthy, term neonates. Informed consent was obtained, and the institutional review board of the Children's Hospital of Philadelphia has approved the present study. Briefly, placental cord blood mononuclear cells were separated by centrifugation for 45 min over Ficoll-Paque (Pharmacia, Uppsala, Sweden). The mononuclear layer was collected and washed twice. $\mathrm{CD}_{14}{ }^{+}$monocytes were separated by incubation with CD14 Microbeads (Millenyi Biotec, Auburn, CA, U.S.A.) for $15 \mathrm{~min}$ at $6-12^{\circ} \mathrm{C}$. After wash, $\mathrm{CD} 14^{+}$monocytes were selected by a positive selection column as instructed by manufacturer. Purified monocytes were resuspended in DMEM supplemented with $10 \%$ fetal bovine serum, $2 \mathrm{mM}$ glutamine, penicillin (100 $\mathrm{U} / \mathrm{mL})$, and streptomycin $(100 \mu \mathrm{g} / \mathrm{mL})$, and plated in 48-well culture plates at a density of $0.25 \times 10^{6}$ cells/well. Isolated monocytes are $>98 \%$ pure as assessed by flow cytometry using MAb against CD14 ${ }^{+}$(Leu-M3).

Flow cytometry analysis. Placental CM and CMDM were analyzed by flow cytometry to determine CCR 5 expression on cell surface. At designated time points (d $0,2,4,6$, and 8), 0.5 $\times 10^{6}$ cells were removed by gently scraping from a culture well in 24-well plates. Cells were incubated with fluoresceinconjugated antibodies against CCR5 (R \& D Systems, Minneapolis, MN, U.S.A.) for $45 \mathrm{~min}$ at $4^{\circ} \mathrm{C}$. Isotope-matched IgG1 labeled with fluorescein was used as a control (Pharmingen, San Diego, CA, U.S.A.). Cells were then washed with prechilled $1 \times$ PBS and re-suspended in $300 \mu \mathrm{L}$ of $1 \%$ paraformaldehyde. Fluorescence was analyzed on a FacsCaliber flow cytometer (BD Biosciences, San Diego, CA, U.S.A.).

PCR analysis for CCR5. To study the mRNA expression of CCR5 receptor during CM differentiation into macrophages $(0$, 2, 4, 6, and $8 \mathrm{~d}$ in culture), RT-PCR was performed with oligonucleotide primer pairs specific for CCR5 receptor. Total cellular RNA was extracted by the single-step method of isolation using Tri Reagent (Molecular Research Center, Cin- cinnati, OH, U.S.A.) One-fifth of the total RNA samples were then reverse transcribed using Reverse Transcription System (Promega, Madison, WI, U.S.A.) with the specific primers for CCR5 (antisense) and $\beta$-actin for $1 \mathrm{~h}$ at $42^{\circ} \mathrm{C}$, and the resulting cDNA was used as a template for PCR amplification. PCR amplification was performed with one-tenth of the cDNA for 35 cycles with AmpliTaq Gold (PerkinElmer, Branchburg, NJ, U.S.A.) in a GeneAmp PCR system 2400 (PerkinElmer-Cetus, Norwalk, CT, U.S.A.). The PCR reaction mixture contained $0.2 \mathrm{mM}$ of deoxyribonucleoside triphosphate, $20 \mathrm{pM}$ of each of two primers, and $1.5 \mathrm{U}$ of AmpliTaq Gold in $1 \times$ reaction buffer (PerkinElmer). PCR amplification consisted of heat inactivation of AmpliTaq Gold for $8 \mathrm{~min}$ at $95^{\circ} \mathrm{C}$, followed by 35 cycles of $94^{\circ} \mathrm{C}$ for $30 \mathrm{~s}, 55^{\circ} \mathrm{C}$ for $30 \mathrm{~s}$, and $72^{\circ} \mathrm{C}$ for $30 \mathrm{~s}$ and further elongation at $72^{\circ} \mathrm{C}$ for $7 \mathrm{~min}$, using the specified CCR5 primers: 5'-CAAAAAGAAGGTCTTCATTAC-ACC-3' (sense), and 5'-CCTGTGCCTCTTCTTCTCATTTC-3' (antisense). The oligonucleotides were synthesized by Integrated DNA Technologies (Coralville, IA, U.S.A.). $\beta$-actin was used as a control to monitor the amount and integrity of RNA in each sample. PCR samples were analyzed by electrophoresis gel separation, using $4 \%$ NuSieve agarose gel for the separation of the CCR5 products and $2 \%$ NuSieve agarose gel for the separation of the $\beta$-actin products.

HIV infection and RT assay. Neonatal monocytes and macrophages cultured in 48 -well plates $\left(0.25 \times 10^{6}\right.$ cells/well $)$ were infected with HIV Balstrain $\left(3 \times 10^{6} \mathrm{CPM} / \mathrm{mL}\right.$ of RT activity). The cells were washed three times with DMEM to remove unabsorbed virus $1 \mathrm{~h}$ after infection. Supernatants were collected for RT activity every $4 \mathrm{~d}$. To determine the level of RT activity, $10 \mu \mathrm{L}$ of culture supernatant was added to $50 \mu \mathrm{L}$ of a cocktail containing poly (A), oligo (dt), $\mathrm{MgCl}_{2}$, Nonidet $\mathrm{p}-40$, and ${ }^{32} \mathrm{P}$ deoxythymidine 5 -triphosphate, and incubated for $20 \mathrm{~h}$ at $37^{\circ} \mathrm{C}$. Thirty microliters of the reaction mixture was then spotted on DE 81 paper and air-dried. The filters were then washed in $2 \times$ standard saline citrate (SSC; $0.3 \mathrm{M} \mathrm{NaCl} /$ $0.03 \mathrm{M}$ sodium citrate, $\mathrm{pH} 7$ ) and $100 \%$ ethanol, dried, cut, and placed in a scintillation counter (2200CA TRI-CARB Liquid Scintillation Analyzer, Packard Instrument Company, Meriden, CT, U.S.A.) for measurement of radioactivity.

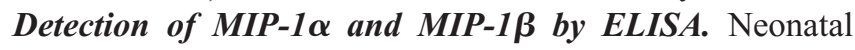
monocytes and macrophages (d $0,2,4,6$, and 8 in culture, 0.25 $\times 10^{6}$ cells/well in a 48 -well plate) were treated with LPS (Sigma Chemical, St. Louis, MO, U.S.A.) at concentration of $100 \mathrm{pg} / \mathrm{mL}$. The culture supernatant was collected and analyzed for MIP- $1 \alpha$ and MIP-1 $\beta$ production $24 \mathrm{~h}$ post-treatment. MIP- $1 \alpha$ and MIP- $1 \beta$ in the culture supernatants were determined using ELISA (Endogen, Woburn, MA, U.S.A.). The sensitivity of the assay was $4 \mathrm{pg} / \mathrm{mL}$ for both MIP- $1 \alpha$ and MIP-1 $\beta$.

\section{RESULTS}

Expression of CCR5 on CM and CMDM. To investigate whether CCR5 receptor expression was altered during the differentiation of CM to CMDM, the flow cytometry was performed to analyze the expression of CCR5 on the cell surface. The levels of CCR5 receptor expression on CM (d 0) 
were significantly lower $(9.4 \%)$ than those on 8 -d-cultured CMDM (50.7\%) (Fig. 1A). The steadily increased expression of CCR 5 on the cell surface (Fig. $1 B$ ) was observed during the course of CM differentiation into $\operatorname{CMDM}(2,4,6$, and $8 \mathrm{~d}$ in cultures).

CCR5 mRNA levels in CM and CMDM. To determine whether expression of CCR5 receptor on the cell surface is related to CCR5 mRNA expression during the differentiation of $\mathrm{CM}$ to CMDM, CCR5 mRNA extracted from $\mathrm{CM}$ and CMDM was examined by RT-PCR. CCR5 mRNA was present in both freshly isolated CM and cultured CMDM. The levels of CCR5 mRNA remained relatively constant as CM differentiated into CMDM (Fig. 2).

Production of $\beta$-chemokines by CM and CMDM. When treated with LPS, freshly isolated CM (d 0) and cultured CMDM (d 8) produced $\beta$-chemokines (MIP- $1 \alpha$ and MIP- $1 \beta$ ) at similar levels (Fig. 3). HIV Bal-infected CMDM, however, showed a significant increase in levels of $\beta$-chemokines (Fig. 4). HIV-exposed CM (d 0) produced MIP- $1 \alpha$ and MIP- $1 \beta$ at a mean concentration of $230 \mathrm{pg} / \mathrm{mL}$ and $450 \mathrm{pg} / \mathrm{mL}$, respectively, whereas HIV infection of CMDM (d 8 in cultures) yielded $820 \mathrm{pg} / \mathrm{mL}$ and $1093 \mathrm{pg} / \mathrm{mL}$ of MIP- $1 \alpha$ and MIP- $1 \beta$, respectively. The increased levels of $\beta$-chemokines are positively correlated with HIV RT activity (Fig. 4). There was no significant difference between MIP- $1 \alpha$ and MIP- $1 \beta$ expression during $\mathrm{CM}$ differentiation into CMDM and HIV infection of these cells.

Susceptibility of CM and CMDM to HIV infection. The levels of HIV RT activity in culture supernatants were also assayed in the cultures of CM and CMDM at 4, 8, and $12 \mathrm{~d}$ postinfection with HIV Bal strain. As demonstrated in Figure 5 , freshly isolated cord monocytes ( $0 \mathrm{CM}$ ) were refractory to HIV infection as demonstrated by low RT activities. However, significantly increased HIV RT activities were observed in d 8 CMDM cultures. Although RT activity in $\mathrm{d} 0 \mathrm{CM}$ and $\mathrm{d} 8$ CMDM varied among individual cord blood samples, the HIV infectivity in $\mathrm{d} 0 \mathrm{CM}$ was significantly lower than that in $\mathrm{d} 8$ CMDM at 8 or $12 \mathrm{~d}$ post infection (Fig. 5).

A
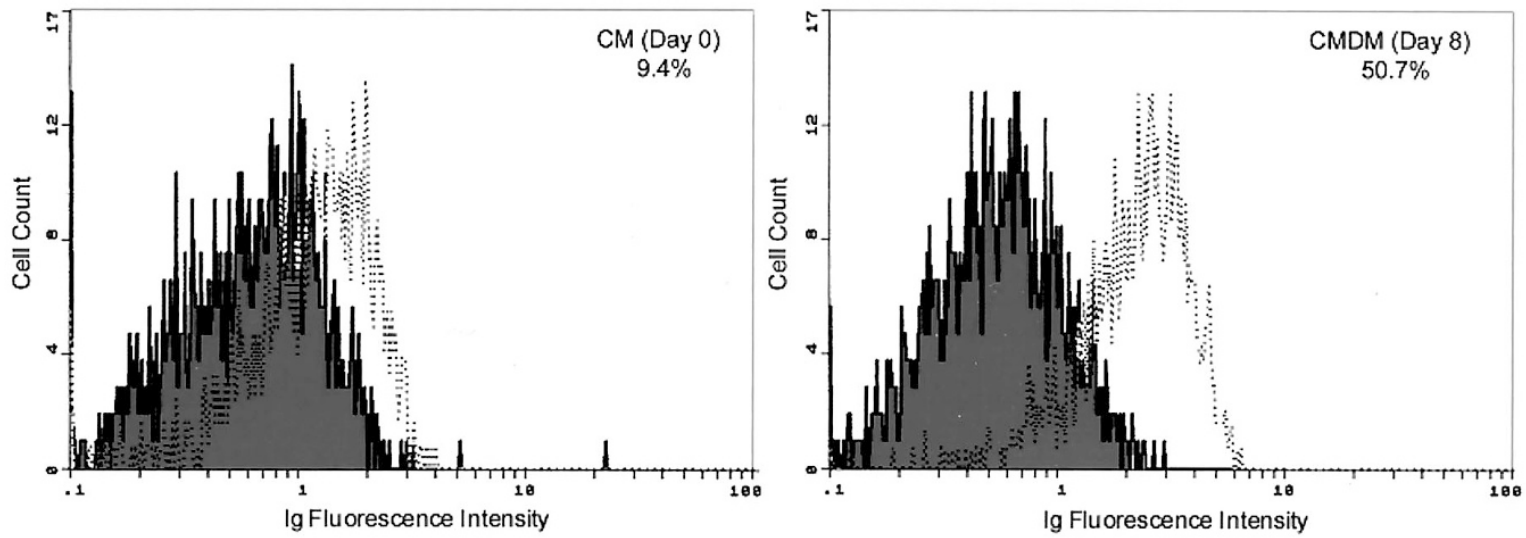

B

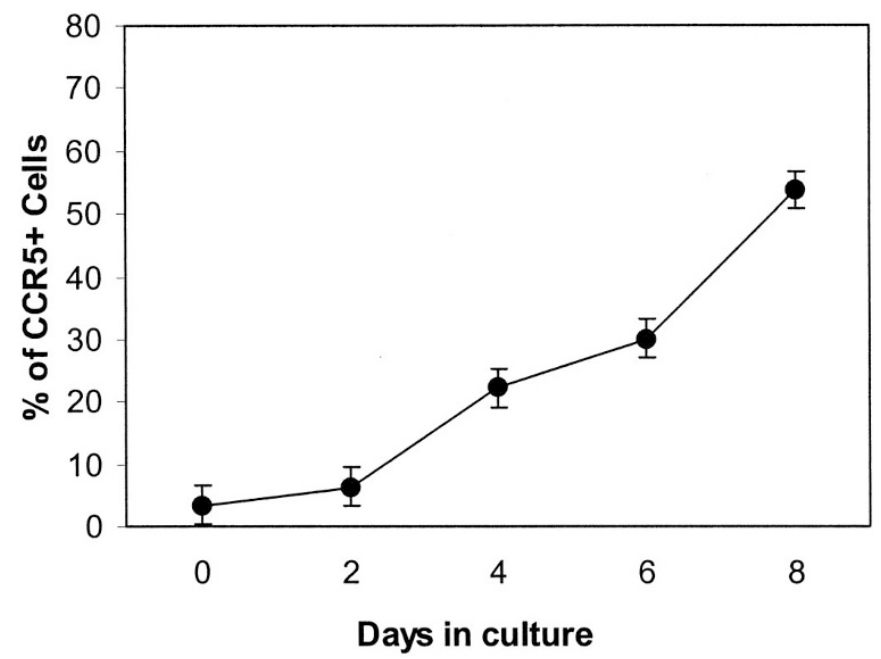

Figure 1. (A) Flow cytometry analysis of CCR5 surface protein expression on the membrane of freshly isolated CM and CMDM. CM (d 0) and CMDM (d 8) were stained with a mouse MAb against CCR5 (2D7). The shaded histogram represents control staining with isotype-matched antibody (IgG 2a). The open histogram represents CCR5 expression using the 2D7. The results are shown as the percentage of CCR5-positive cells and are representative of five cord blood samples. $(B)$ Effect of stage of differentiation of CM on CCR5 surface protein expression. The cells were harvested at the indicated time above and stained with a monoclonal mouse antibody to CCR5 (2D7) or an isotype-matched antibody (IgG 1) for flow cytometry. The results shown are mean \pm SD of duplicate cultures and are representative of five experiments using the cells from five different cord blood samples. 


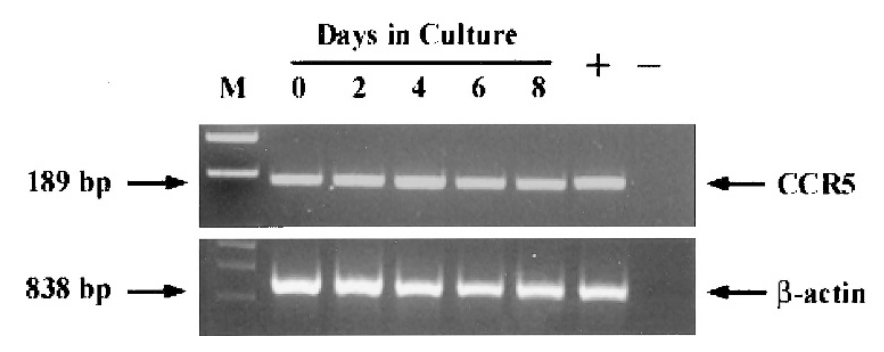

Figure 2. RT-PCR analysis of CCR5 mRNA during differentiation of cord monocytes to macrophages. Cord monocytes were prepared and cultured as described in "Materials and Methods." Total cellular mRNA was extracted from the cultured cells at the indicated time and subjected to RT-PCR assay using specific primers for $(A)$ CCR5 and $(B) \beta$-actin. Representative results from five different cord blood samples are shown.

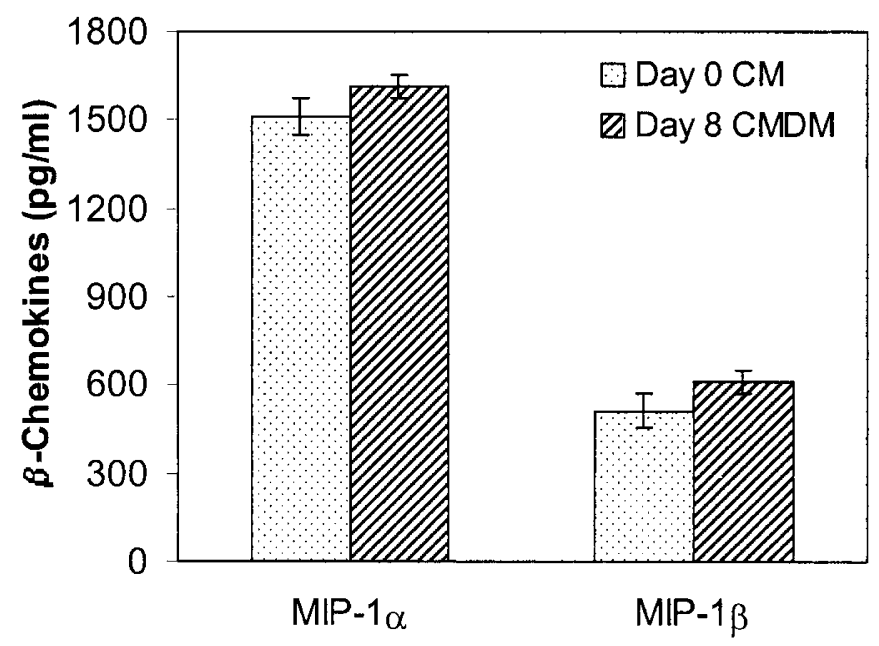

Figure 3. Production of MIP- $1 \alpha$ and MIP- $1 \beta$ in CM and CMDM. Freshly isolated (d 0) CM and 8-d-cultured CMDM were treated with LPS (100 $\mathrm{ng} / \mathrm{mL}$ ) and culture supernatants were collected 24-h post LPS treatment. The results shown are mean $\pm \mathrm{SD}$ of triplicate cultures and are representative of five experiments using the cells from five different cord blood samples.

\section{DISCUSSION}

The macrophage is a major target of HIV in vivo, and plays an important role in the persistence of infection, serving as a viral reservoir $(1,2)$. In cell culture, blood-derived monocytes differentiate into macrophages, which mimics in vivo monocyte differentiation into macrophages in tissues. Immature monocytes in the blood infiltrate tissues and organs, becoming macrophages that express various enzymes and cell surface antigens (2). In the present study, we have demonstrated that $\mathrm{CM}$ and CMDM have distinct differences in their susceptibility to infection by HIV Bal strain. The degree of susceptibility to HIV Bal infection was clearly associated with the stage of differentiation of CM during in vitro culture. The increased susceptibility to HIV infection by macrophages during in vitro differentiation is not related to the expression of CD4 receptors (1, 27-29). In fact, CD4 expression on both cord and adult MDM was decreased at time (7-10 d) of HIV infection (1). Thus, other factors other than CD4 are involved in cell susceptibility to HIV infection. Our data show that in vitro $\mathrm{CM}$ differentiation was associated with the increased expression of CCR5 receptor, a major co-receptor for the entry of HIV macrophage-tropic strains into macrophages and CD4+ T lymphocytes $(3-5,7)$. Thus, up-regulation of CCR5 expression on CMDM is a possible mechanism responsible for the increased susceptibility of CMDM to HIV Bal strain infection.

The differentiation of adult blood monocytes into macrophages was accompanied by up-regulation of CCR 5 expression (26). Fear et al. (30) reported more increased cell surface CCR5 on CMDM than CM. We previously showed a progressive decrease in CCR5 cell surface expression during CM differentiation into macrophages (31). These different observations may be the result of differences in the cell isolation methods. It is highly possible that CM were activated in the process of purification using gelatin-coated flasks (our previously used technique) (32). In the present study, we use MACS CD14 MicroBeads to purify monocytes and observed higher

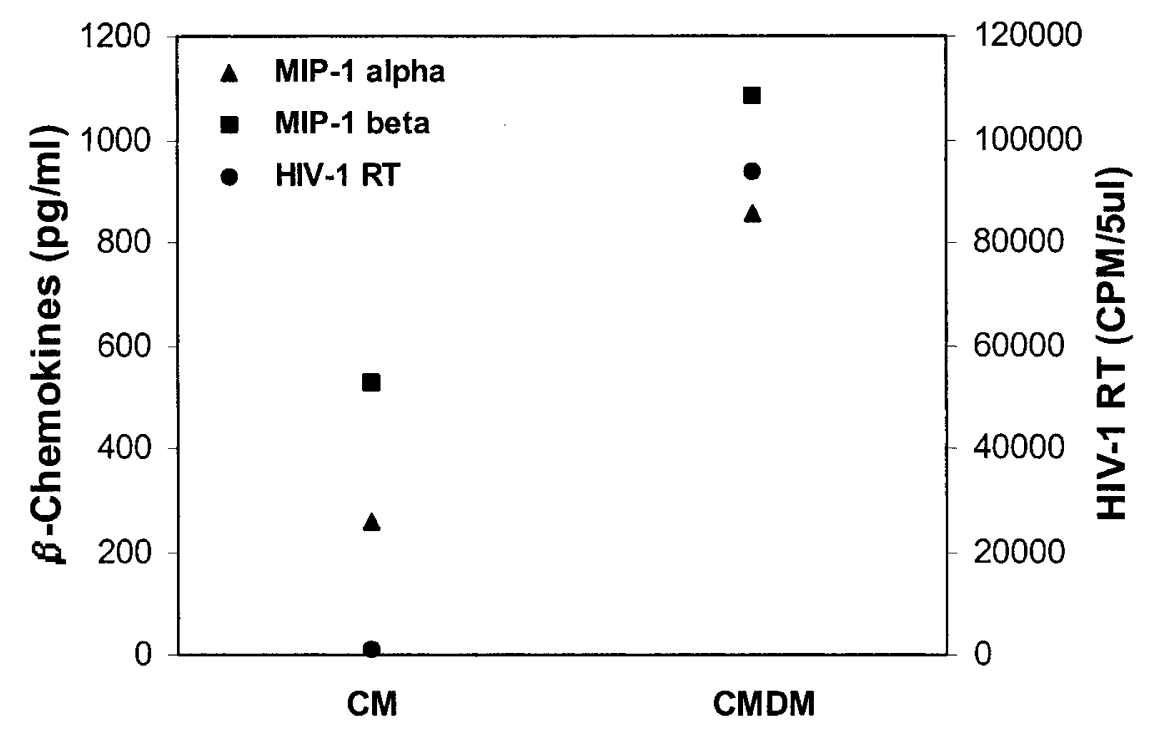

Figure 4. Production of MIP-1 $\alpha$ and MIP-1 $\beta$ in HIV-infected CM and CMDM. Freshly isolated (d 0) CM and 8-d-cultured CMDM were infected with HIV Bal stain. Culture supernatants were collected for MIP- $1 \alpha$ and MIP- $1 \beta$ analysis $4 \mathrm{~d}$ postinfection. Results are representative of four experiments using the cells from four different cord blood samples. 

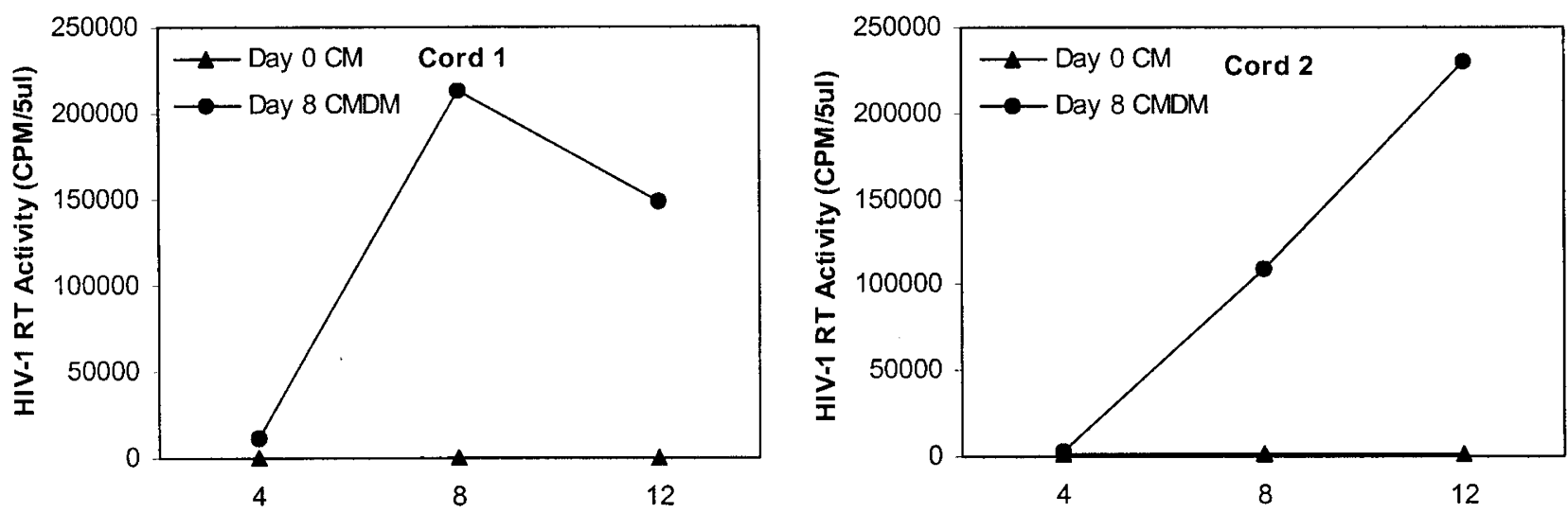

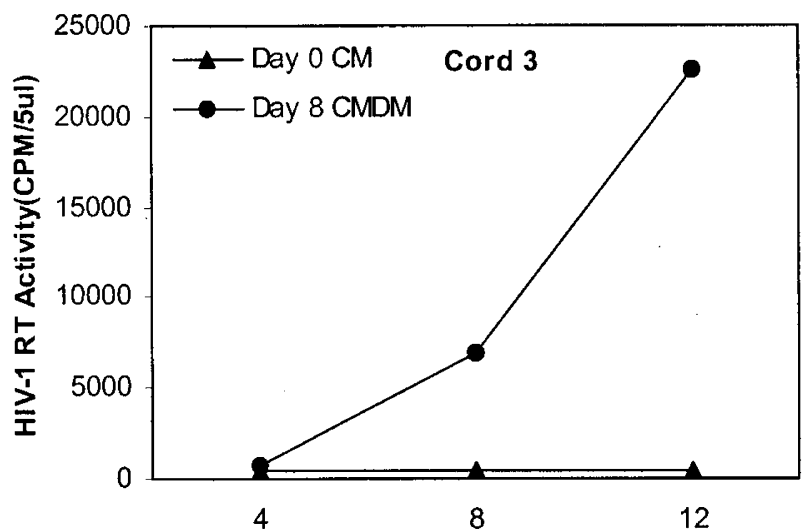

Days Post-infection

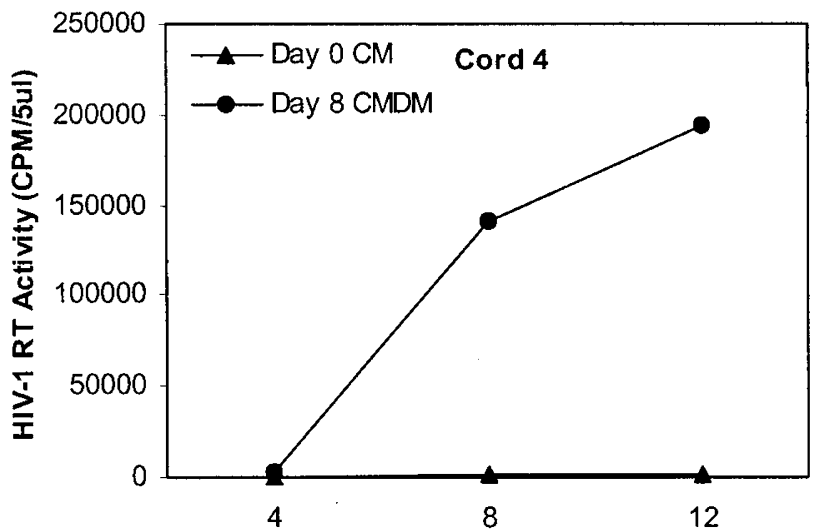

Days Post-infection

Figure 5. HIV infection of placental CM and CMDM. Freshly isolated cord monocytes (d $0 \mathrm{CM}$ ) and 8-d-cultured cord monocyte-derived macrophages (d 8 CMDM) were infected with HIV Bal strain. Culture supernatants were collected at the indicated time points after HIV infection (d 4, 8, 12), and assayed for HIV RT activity. Each graph represents an individual cord blood sample (cord 1, 2, 3, and 4).

levels of membrane CCR5 expression on CMDM compared with freshly isolated CM. Low levels of membrane CCR5 expression on freshly isolated $\mathrm{CM}$ contributed to their limited susceptibility to HIV Bal strain infection. In contrast, CMDM with high levels of CCR5 expression were highly susceptible to HIV Bal strain infection. Interestingly, although freshly isolated CM expressed significantly lower levels of CCR5 receptors on the cell membrane than those on CMDM, the levels of CCR5 mRNA in CM are similar to those in 8-d-cultured CMDM (Fig. 2). This finding suggests that regulation of CCR5 receptor during $\mathrm{CM}$ maturation occurs at the post-transcriptional level. Our data extend the observation by Fear et al. (30), who showed no significant increase in CCR5 mRNA in 7-dcultured macrophages in comparison to monocytes (d 1 postisolation). Our findings are in contrast to Naif et al (22) and Tuttle et al (24), who demonstrated that freshly isolated adult blood monocytes expressed significantly lower levels of CCR5 mRNA than those expressed by 5-d-cultured adult blood macrophages, which was correlated with the low level expression of CCR5 on the cell surface of monocytes. A recent study demonstrated that during the course of monocyte differentiation into macrophage, both mRNA and protein expression of CCR5 increased (33). The discrepancy between our observa- tions and others may be due to the difference in PCR amplification cycle numbers and the antibodies used for the detection of CCR5 receptor on the cell membrane. In addition, we used placental cord monocyte/macrophages in this study, which also may contribute the observed discrepancy.

$\beta$-chemokines (MIP- $1 \alpha$, MIP-1 $\beta$, and RANTES) are the natural ligands for CCR5 receptor (10-12) and inhibit infection by competing with HIV for CCR5 receptor. Increased levels of $\beta$-chemokines have been shown to inhibit HIV infection (34). HIV infection induces $\beta$-chemokine productions (12, 35,36 ), which presumably play a crucial role in recruiting uninfected $\mathrm{T}$ cells and monocytes to sites of active viral replication (35). Thus, differential expression of $\beta$-chemokines may contribute to the observed difference in susceptibility of $\mathrm{CM}$ and CMDM to HIV infection. We examined the role of $\beta$-chemokines in HIV infection of CM and CMDM. We observed little change in the levels of $\beta$-chemokines during $\mathrm{CM}$ differentiation into CMDM. A significant increase in the levels of $\beta$-chemokines, however, was observed in 8-d-cultured CMDM infected with HIV Bal strain (Fig. 4). This induction is dependent upon viral replication, because the increased production of $\beta$-chemokines was positively correlated with HIV RT activity (Fig. 4). Our data support the studies using adult 
peripheral blood monocytes, showing that HIV-infected macrophages elaborate $\beta$-chemokines both in vitro and in vivo (35). The increased $\beta$-chemokines may enhance the spread of infection through their chemoattractive effects on leukocytes, which may have important implication in perinatal HIV infection.

Taken together, our data provide new insights into the mechanism of differential susceptibility of CM and CMDM to HIV infection in vitro. Neonate monocyte/macrophages play an important role in the pathogenesis of perinatal HIV infection, because these cells are critical in antigen processing and presentation to both $\mathrm{T}$ and $\mathrm{B}$ lymphocytes. HIV infection of neonate monocyte/macrophages may damage their ability to process and present antigen in the normal immune response (37). Our data have provided further understanding of the role of $\beta$-chemokines and CCR5 in the pathogenesis of pediatric HIV infection.

\section{REFERENCES}

1. Ho WZ, Lioy J, Song L, Cutilli JR, Polin RA, Douglas SD 1992 Infection of cord blood monocyte-derived macrophages with human immunodeficiency virus type 1 . J Virol 66:573-579

2. Ho WZ, Cherukuri R, Douglas SD 1994 The macrophage and HIV-1. In: Zwilling BS, Eisenstein TK (eds) Macrophage-Pathogen Interactions, Immunol Ser. Marcel Dekker, New York, pp 569-587

3. Alkhatib G, Combadiere C, Broder CC, Feng Y, Kennedy PE, Murphy PM, Berger EA 1996 CC CKR5: a RANTES, MIP-1alpha, MIP-1beta receptor as a fusion cofactor for macrophage-tropic HIV-1. Science 272:1955-1958

4. Deng H, Liu R, Ellmeier W, Choe S, Unutmaz D, Burkhart M, Di Marzio P, Marmon S, Sutton RE, Hill CM, Davis CB, Peiper SC, Schall TJ, Littman DR, Landau NR 1996 Identification of a major co-receptor for primary isolates of HIV-1. Nature 381:661-666

5. Dragic T, Litwin V, Allaway GP, Martin SR, Huang Y, Nagashima KA, Cayanan C, Maddon PJ, Koup RA, Moore JP, Paxton WA 1996 HIV-1 entry into CD4+ cells is mediated by the chemokine receptor CC- CKR-5. Nature 381:667-673

6. Dean M, Carrington M, Winkler C, Huttley GA, Smith MW, Allikmets R, Goedert JJ, Buchbinder SP, Vittinghoff E, Gomperts E, Donfield S, Vlahov D, Kaslow R, Saah A Rinaldo C, Detels R, O'Brien SJ 1996 Genetic restriction of HIV-1 infection and progression to AIDS by a deletion allele of the CKR5 structural gene. Hemophilia Growth and Development Study, Multicenter AIDS Cohort Study, Multicenter Hemophilia Cohort Study, San Francisco City Cohort, ALIVE Study. Science 273:1856-1862

7. Huang Y, Paxton WA, Wolinsky SM, Neumann AU, Zhang L, He T, Kang S, Ceradini D, Jin Z, Yazdanbakhsh K, Kunstman K, Erickson D, Dragon E, Landau NR, Phair J, Ho DD, Koup RA 1996 The role of a mutant CCR5 allele in HIV-1 transmission and disease progression. Nat Med 2:1240-1243

8. Liu R, Paxton WA, Choe S, Ceradini D, Martin SR, Horuk R, MacDonald ME, Stuhlmann H, Koup RA, Landau NR 1996 Homozygous defect in HIV-1 coreceptor accounts for resistance of some multiply-exposed individuals to HIV-1 infection. Cell 86:367-377

9. Samson M, Libert F, Doranz BJ, Rucker J, Liesnard C, Farber CM, Saragosti S, Lapoumeroulie C, Cognaux J, Forceille C, Muyldermans G, Verhofstede C, Burtonboy G, Georges M, Imai T, Rana S, Yi Y, Smyth RJ, Collman RG, Doms RW, Vassart G, Parmentier M 1996 Resistance to HIV-1 infection in Caucasian individuals bearing mutant alleles of the CCR-5 chemokine receptor gene. Nature 382:722-725

10. Ullum H, Cozzi Lepri A, Victor J, Aladdin H, Phillips AN, Gerstoft J, Skinhoj P, Pedersen BK 1998 Production of beta-chemokines in human immunodeficiency virus (HIV) infection: evidence that high levels of macrophage inflammatory protein-1beta are associated with a decreased risk of HIV disease progression. J Infect Dis 177:331-336

11. Arenzana-Seisdedos F, Virelizier JL, Rousset D, Clark-Lewis I, Loetscher P, Moser B, Baggiolini M 1996 HIV blocked by chemokine antagonist. Nature 383:400
12. Mackewicz CE, Barker E, Greco G, Reyes-Teran G, Levy JA 1997 Do betachemokines have clinical relevance in HIV infection? J Clin Invest 100:921-930

13. Schuit KE, Powell DA 1980 Phagocytic dysfunction in monocytes of normal newborn infants. Pediatrics 65:501-504

14. Pahwa SG, Pahwa R, Grimes E, Smithwick E 1977 Cellular and humoral components of monocyte and neutrophil chemotaxis in cord blood. Pediatr Res 11:677-680

15. Klein RB, Fischer TJ, Gard SE, Biberstein M, Rich KC, Stiehm ER 1977 Decreased mononuclear and polymorphonuclear chemotaxis in human newborns, infants, and young children. Pediatrics 60:467-472

16. Das M, Klein W, Feig SA 1977 Glycolytic metabolism of neonatal mononuclear cells. Pediatr Res 11:1068-1072

17. Bryson YJ, Winter HS, Gard SE, Fischer TJ, Stiehm ER 1980 Deficiency of immune interferon production by leukocytes of normal newborns. Cell Immunol 55:191-200

18. Taylor S, Bryson YJ 1985 Impaired production of gamma-interferon by newborn cells in vitro is due to a functionally immature macrophage. J Immunol 134:1493-1497

19. Hariharan D, Ho W, Cutilli J, Campbell DE, Douglas SD 2000 C-C chemokine profile of cord blood mononuclear cells: selective defect in RANTES production. Blood 95:715-718

20. Sperduto AR, Bryson YJ, Chen IS 1993 Increased susceptibility of neonatal monocyte/macrophages to HIV-1 infection. AIDS Res Hum Retroviruses 9:1277-1285

21. Reinhardt PP, Reinhardt B, Lathey JL, Spector SA 1995 Human cord blood mononuclear cells are preferentially infected by non-syncytium-inducing, macrophagetropic human immunodeficiency virus type 1 isolates. J Clin Microbiol 33:292-297

22. Naif HM, Li S, Ho-Shon M, Mathijs JM, Williamson P, Cunningham AL 1997 The state of maturation of monocytes into macrophages determines the effects of IL-4 and IL-13 on HIV replication. J Immunol 158:501-511

23. Olafsson K, Smith MS, Marshburn P, Carter SG, Haskill S 1991 Variation of HIV infectibility of macrophages as a function of donor, stage of differentiation, and site of origin. J Acquir Immune Defic Syndr 4:154-164

24. Tuttle DL, Harrison JK, Anders C, Sleasman JW, Goodenow MM 1998 Expression of CCR5 increases during monocyte differentiation and directly mediates macrophage susceptibility to infection by human immunodeficiency virus type 1. J Virol 72:49624969

25. Rich EA, Chen IS, Zack JA, Leonard ML, O’Brien WA 1992 Increased susceptibility of differentiated mononuclear phagocytes to productive infection with human immunodeficiency virus-1 (HIV-1). J Clin Invest 89:176-183

26. Di Marzio P, Tse J, Landau NR 1998 Chemokine receptor regulation and HIV type 1 tropism in monocyte- macrophages. AIDS Res Hum Retroviruses 14:129-138

27. Gendelman HE, Orenstein JM, Baca LM, Weiser B, Burger H, Kalter DC, Meltzer MS 1989 The macrophage in the persistence and pathogenesis of HIV infection. AIDS 3:475-495

28. Kazazi F, Mathijs JM, Foley P, Cunningham AL 1989 Variations in CD4 expression by human monocytes and macrophages and their relationships to infection with the human immunodeficiency virus. J Gen Virol 70:2661-2672

29. Valentin A, Matsuda S, Asjo B 1990 Characterization of the in vitro maturation of monocytes and the susceptibility to HIV infection. AIDS Res Hum Retroviruses 6:977-978

30. Fear WR, Kesson AM, Naif H, Lynch GW, Cunningham AL 1998 Differential tropism and chemokine receptor expression of human immunodeficiency virus type 1 in neonatal monocytes, monocyte-derived macrophages, and placental macrophages. J Virol 72:1334-1344

31. Hariharan D, Douglas SD, Lee B, Lai JP, Campbell DE, Ho WZ 1999 Interferongamma upregulates CCR5 expression in cord and adult blood mononuclear phagocytes. Blood 93:1137-1144

32. Hassan NF, Cutilli JR, Douglas SD 1990 Isolation of highly purified human blood monocytes for in vitro HIV-1 infection studies of monocyte/macrophages. J Immunol Methods 130:283-285

33. Kaufmann A, Salentin R, Gemsa D, Sprenger H 2001 Increase of CCR1 and CCR5 expression and enhanced functional response to MIP-1 alpha during differentiation of human monocytes to macrophages. J Leukoc Biol 69:248-252

34. Cocchi F, DeVico AL, Garzino-Demo A, Arya SK, Gallo RC, Lusso P 1995 Identification of RANTES, MIP-1 alpha, and MIP-1 beta as the major HIVsuppressive factors produced by CD8+ T cells. Science 270:1811-1815

35. Schmidtmayerova H, Nottet HS, Nuovo G, Raabe T, Flanagan CR, Dubrovsky L, Gendelman HE, Cerami A, Bukrinsky M, Sherry B 1996 Human immunodeficiency virus type 1 infection alters chemokine beta peptide expression in human monocytes: implications for recruitment of leukocytes into brain and lymph nodes. Proc Nat Acad Sci U S A 93:700-704

36. Canque B, Rosenzwajg M, Gey A, Tartour E, Fridman WH, Gluckman JC 1996 Macrophage inflammatory protein-1alpha is induced by human immunodeficiency virus infection of monocyte-derived macrophages. Blood 87:2011-2019

37. Baldwin GC, Fleischmann J, Chung Y, Koyanagi Y, Chen IS, Golde DW 1990 Human immunodeficiency virus causes mononuclear phagocyte dysfunction. Proc Natl Acad Sci U S A 87:3933-3937 